\title{
Application of the IWM-PL Model for the Life Cycle Assessment (LCA) of Municipal Waste Management in Krakow. Part 2**
}

\section{Introduction}

Life cycle assessment (LCA) is a tool for evaluating environmental aspects and potential environmental impacts, initially developed for evaluation of a product's life cycle. LCA can be also employed for evaluating the environmental performance of the waste management systems. The assessment time frame stretches from the moment when waste is generated until its final disposal take place. Several waste LCA tools have been developed so far to model the environmental impact of waste management systems. In 2011 a first Polish language application, the IWM-PL model, was issued.

The goal of this study is the quantification of the environmental impacts from the municipal waste management system in Krakow, state in 2010, employing the IWM-PL model.

In the first part of the study, in the paper entitled Application of the IWM-PL Model for the Life Cycle Assessment (LCA) of Municipal Waste Management in Krakow. Part 1 [12] the goal and the scope of the analysis was shown as well as the detailed life cycle inventory of the municipal waste management system in Krakow. The life cycle inventory results, shown in the previous paper, are input for the next phase of life cycle assessment (LCA), that is life cycle impact assessment (LCIA). The results are obtained by applying the IWM-PL model, the first Polish language application for conducting LCA of waste management systems.

* AGH University of Science and Technology, Faculty of Mining Surveying and Environmental Engineering, Krakow, Poland

** The work was completed within the scope of AGH University of Science and Technology statutory research for the Department of Environmental Management and Protection no. 11.11.150.008. 


\section{Methodology}

The ISO 14040 standard [6] recommends performing LCA studies with a fourstep approach:

1. goal and scope,

2. inventory analysis,

3. impact assessment,

4. interpretation.

Goal and scope includes the definition of the aim, the system boundaries and also the functional unit. These were defined in a previous paper Application of the IWM-PL Model for the Life Cycle Assessment (LCA) of Municipal Waste Management in Krakow. Part 1 [12]. In the life cycle inventory (LCI) phase an inventory of all inputs and outputs of the system is made [26]. Results of the life cycle inventory are thoroughly explained in the paper Application of the IWM-PL Model for the Life Cycle Assessment (LCA) of Municipal Waste Management in Krakow. Part 1 [12]. In the life cycle impact assessment step, based on the results of the inventory analysis (quantified inputs and outputs), environmental impacts are estimated. They are grouped and quantified into a limited number of impact categories. Finally, in the interpretation phase, the results are analysed and recommendations are derived.

The life cycle impact assessment phase of an LCA is the evaluation of potential human health and environmental impacts of the environmental resources and contaminations identified during the LCI. Impact assessment is performed in several steps [7]:

1. selection and definition of impact categories - identifying relevant environmental impact categories;

2. classification - assigning LCI results to the impact categories;

3. characterization - modelling LCI impacts within impact categories using science-based conversion factors;

4. normalization - expressing potential impacts in ways that can be compared;

5. grouping - sorting or ranking the indicators;

6. weighting - emphasizing the most important potential impacts;

7. evaluating and reporting LCIA results - gaining a better understanding of the reliability of the LCIA results.

The last phase of the LCA process is the life cycle interpretation. The life cycle interpretation is a systematic technique to identify, quantify, check, and evaluate information from the results of the LCI and the LCIA, and communicate them effectively [7]. ISO has defined the following objective of life cycle interpretation [6]: analyse results, reach conclusions, explain limitations, and provide recommendations based on the findings of the preceding phases of the LCA, and to report the results of the life cycle interpretation in a transparent manner. 
Several methodologies for performing LCIA has been developed. Below are specified frequently used methodologies [8]:

- CML 2002 [13],

- Eco-indicator 99 [10],

- EDIP [14, 27],

- EPS2000 [22],

- Impact 2002+ [3, 21],

- LIME [16],

- LUCAS [25],

- ReCiPe [4],

- Swiss Ecoscarcity or Ecological scarcity [2],

- TRACI [1],

- MEEuP methodology [17].

In the IWM-PL model life cycle impact assessment methodology is based on Eco-indicator 99 [19]. Therefore, the Eco-indicator 99 methodology is described below.

The Eco-indicator 99 is one of the most widely used impact assessment methods in the LCA. It is a damage approach proceeding from the identification of areas of concern (damage categories) to the determination of what causes damage to endpoints. The method considers three damage categories: human health, ecosystem quality and resources $[5,10]$. Table 1 shows the three damage categories and the related impact categories modelled in the Eco-indicator 99. In brackets shortened, simplified names of impact categories have been given, which are used in the further part of the study.

Table 1. The damage categories and related impact categories in the Eco-indicator method

\begin{tabular}{||c|l||}
\hline \hline Damage category & \multicolumn{1}{c||}{ Impact category } \\
\hline \hline \multirow{5}{*}{ Human health } & Carcinogenic effects on humans (carcinogens) \\
\cline { 2 - 3 } & Respiratory effects caused by organic substances (respiratory organics) \\
\cline { 2 - 3 } Ecosystem quality & Respiratory effects caused by inorganic substances (respiratory inorganics) \\
\cline { 2 - 3 } & Damage caused by climate change (climate change) \\
\cline { 2 - 3 } & $\begin{array}{l}\text { Effects caused by ionising radiation (radiation) } \\
\text { (acidification/ eutrophication) }\end{array}$ \\
\cline { 2 - 3 } & Effects caused by ozone layer depletion (ozone layer) \\
\hline \multirow{5}{*}{ Resources } & Damage caused by land occupation and land conversion (land use) \\
\hline & Damages caused by extraction of minerals (minerals) \\
\cline { 2 - 3 } & Damages caused by extraction of fossil fuels (fossil fuels) \\
\hline \hline
\end{tabular}

Source: [5] 
In the impact assessment phase of LCA, the inventory results are processed into the impact categories. In the characterisation stage, the indicator values for each impact category are calculated. For those impact categories which affect human health such as: carcinogens, respiratory organics, respiratory inorganics, climate change, radiations and ozone layer damage, the scores are expressed as DALY (disability adjusted life years). scores for impact categories affecting ecosystem quality are expressed as PDF (potentially disappeared fraction) [5, 11, 18, 20]. Categories concerning resource depletion: "minerals" and "fossil fuels" are related to a parameter that indicates the quality of the remaining resources. The extraction of these resources will result in higher energy requirements for future extraction, that is MJ surplus energy [10].

At the step of characterisation, the categories cannot be compared with each other, as their indicators are expressed in different units. In order to show to what extent an impact category has a significant contribution to the overall environmental problem a normalisation procedure is needed. This is done by dividing the impact category indicators by a normal value. The normal value in the Eco-indicator 99 method is the average environmental impact of a European citizen in one year $[10,11,18,20]$. The normalised results show the order of the magnitude of the environmental problems generated by the product's life cycle, compared to the total environmental loads in Europe [5].

The next step in the impact assessment procedure is weighting. The result obtained through this procedure is expressed as ecopoints $(\mathrm{Pt})$, where one ecopoint can be interpreted as one thousandth of the annual environmental load of one average European inhabitant [5]. However, the weighting of results embeds a high risk of uncertainty, thus those results should be adopted cautiously.

The IWM-PL model does not apply the complete Eco-indicator 99 methodology, but only a limited scope of this methodology. For example the damage category Resources is not taken into account at all. For the damage category: Human health, the impact category Radiation is not included. For the damage category Ecosystem quality only two impact categories are incorporated into the IWM-PL model: Acidification/ Eutrophication and Ecotoxicity, the model does not contain the impact category of land use.

Once the data are introduced into the model and parameters of the waste treatment installations are defined, a Sankey's diagram is generated. The diagram illustrates waste streams/fractions flows between treatment processes with inputs and outputs for individual processes. The waste streams flows are shown as stripes with width proportional to their quantities.

The IWM-PL model calculates emissions to water and air. The quantities of emissions are given in mass units - kilograms for all substances. Then, the IWM-PL model converts emissions into: six impact categories for emission to water and consequently into the same six impact categories for emission to air. As a final result the IWM-PL model creates a graph of the environmental impact in two 
damage categories: Human health and Ecosystem quality. The value of the total environmental impact of the evaluated waste management system is expressed in ecopoints $(\mathrm{Pt})$.

\section{Results and Discussion}

\subsection{Sankey's Diagram}

In the Sankey's diagram (Fig. 1) the flows of the following waste streams are illustrated: mixed (non- separately collected) waste, waste from commercial sector - joining the mixed waste stream, separately collected waste (in this garden waste), bulky waste.

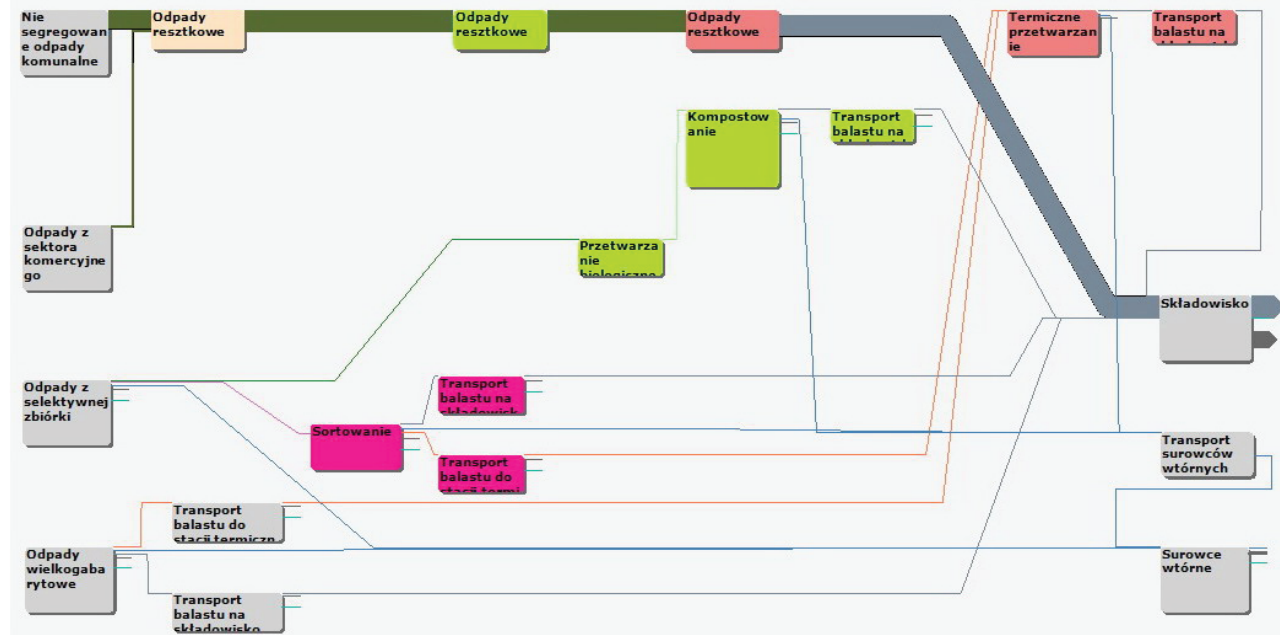

Fig. 1. Sankey's diagram, produced by the IWM-PL model, for the municipal waste management system in Krakow

Source: author's own based on IWM-PL model

For each stream of waste the flows are demonstrated, including the treatment installations. The dominating stream is the mixed waste with the widest stripe. The other flows of waste are quite poor compared to the mixed waste flow. The mixed waste stream ends at the landfill, this treatment installation has the biggest outputs; it means the emissions from landfilling process are the most significant. Concurrently the landfill is the place of final disposal, there is no further flow of waste from this installation. For the other installations: the composting plants, the sorting station, the thermal treatment plant waste streams flow in and flow out. For these flows which go out of the installations, the transport is considered. 
In the Sankey's diagram the dismantling station plant for bulky waste is not shown. In the diagram the bulky waste directly after collection is transported to landfill (part of the bulky waste) and to the thermal treatment (the remaining part of the bulky waste). In fact, in Krakow waste management system, the bulky waste is dismantled at the dismantling station. The part of the remaining waste after the dismantling of bulky waste together with remaining waste after the sorting of separately collected waste is processed into the RDF fuel. Then the fuel is sent to the combustion process in the cement plant outside Krakow (thermal treatment in the diagram). The IWM-PL model does not have the option of processing remaining waste into RDF fuel. The production of RDF fuel, in the IWM-PL model, is possible for non-separately collected waste. Such a process is not realised in Krakow. Therefore, instead of the RDF fuel production, the thermal treatment is shown in the diagram.

\subsection{Emissions to Air and Water}

After introducing the data into the model and defining the parameters of the waste treatment installations the model calculates the emissions to air and water. The thorough explanation of the required data, the process of its calculations and introducing into IWM-PL model was presented in the paper Application of the IWM-PL Model for the Life Cycle Assessment (LCA) of Municipal Waste Management in Krakow. Part 1 [12].

In Table 2 the calculated emissions to air are shown.

The values of emissions to air are both: above and below zero. The values above zero mean the negative impact on the environment, while the values below zero mean the positive impact on the environment, so called avoided impacts. The substance emitted in large quantities is carbon dioxide coming from all processes. For the recycling process the carbon dioxide has the minus value.

Carbon dioxide emissions can be attributed to:

- the demand for electricity for each treatment process, the electricity in Poland is produced in approximately $90 \%$ by combustion coal and lignite i.e. high emission of carbon dioxide,

- combustion of fuel in transport,

- emission of landfill gas, which consists mainly of methane and carbon dioxide.

The minus values of emissions for recycling process for: carbon dioxide, sulphur oxides, nitrogen oxides and other substances can be explained by avoided impacts. For processing secondary raw materials and producing the useful products from them, less energy is needed comparing to processing of virgin ores and other natural resources.

The minus values for the landfilling process for: sulphur oxides, particulate matters, nitrogen oxides and other substances can be assigned to the utilisation of the landfill gas in the sanitary landfill Barycz. The landfill gas is collected by a special pipeline system and further processed into heat and electricity. Production of electricity by methane combustion causes less emission of above mentioned substances than the combustion of coal and lignite for producing the same quantity of electricity.

In Table 3 calculated emissions to water are presented. 


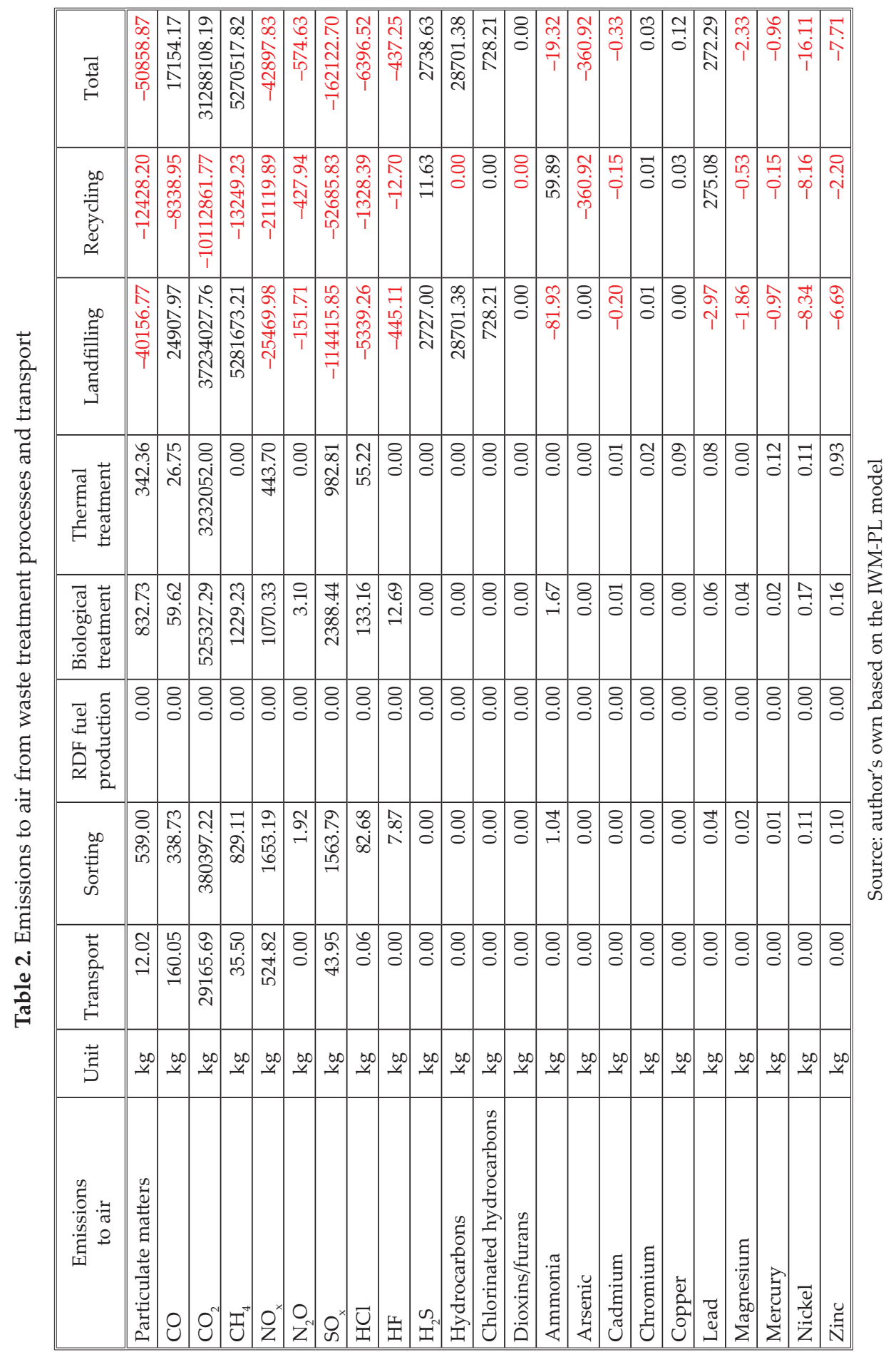




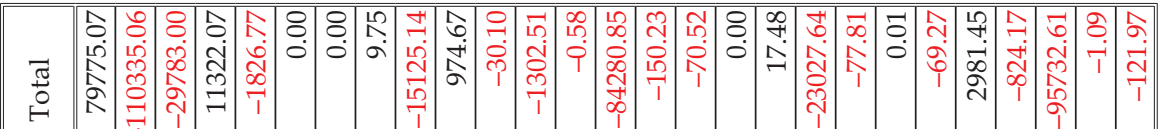

n ద

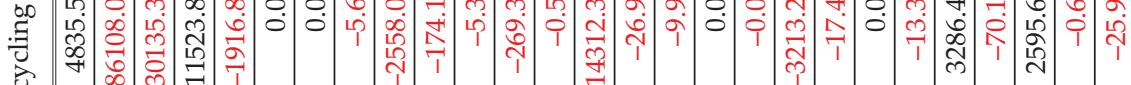

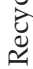

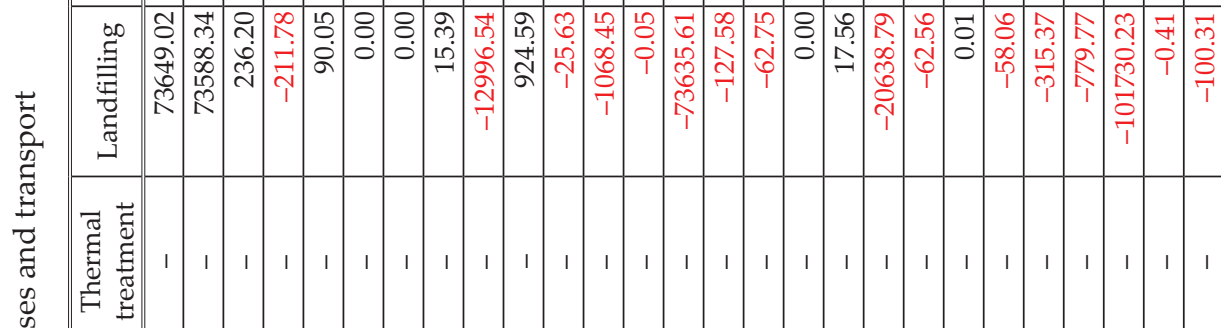

ส ¿্ं

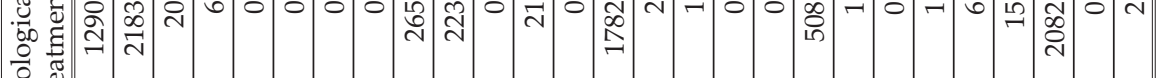
要

ঊ $\sum_{1}^{+}$

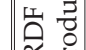

్ํㅇ

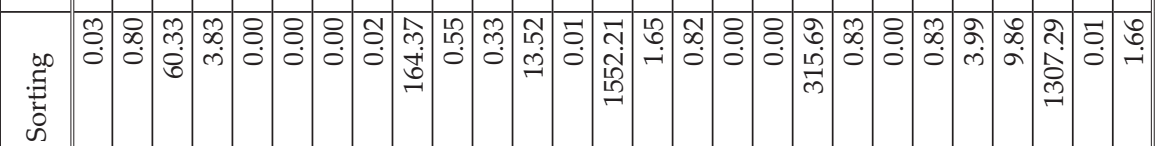
$\sum_{0}$

$$
+
$$

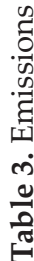

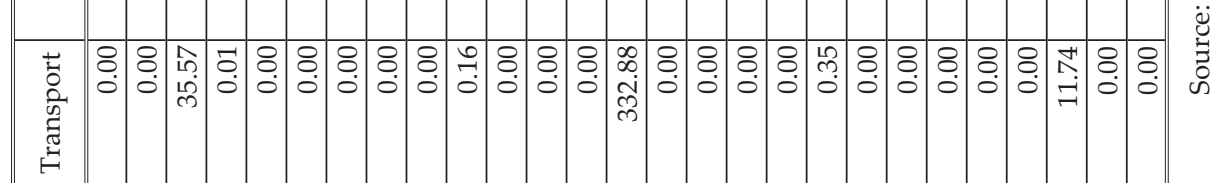

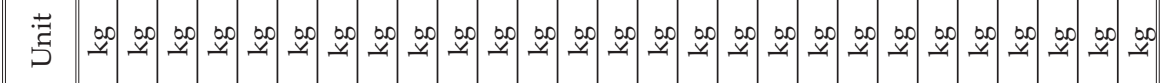

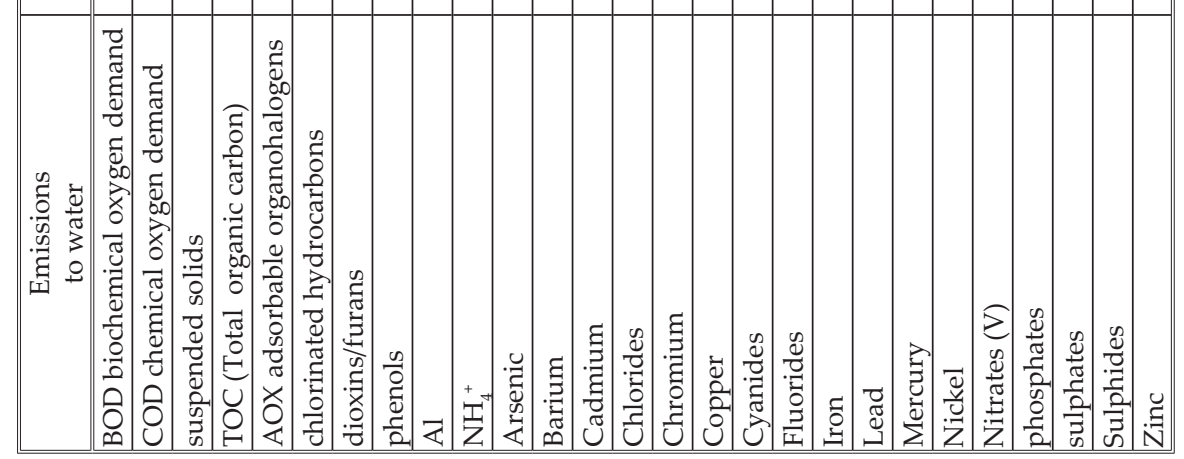


The calculated, in the IWM-PL model, values of emissions to water are astonishing. No emission is shown for the thermal treatment process, while for the same process the significant emissions to air are revealed in the Table 2. Although minus values of emissions for the recycling process for some substances are credible due to the avoided impacts, the minus values for the landfilling process for: sulphates, chlorides, iron, aluminium and other substances are not justified. The disposal process of municipal waste at the sanitary landfill generates extensive quantities of leachate with a substantial load of pollutant substances [9, 15, 23, 24].

Even though the leachate from the Barycz sanitary landfill is collected and sent to the waste water plant, the sewage treatment process does not have $100 \%$ efficiency. It is not possible to explain credibly the minus values (avoided impact) of emission to the water for the landfilling process for so many substances.

The total values, for all treatment processes, for 17 out of 27 substances/parameters are below zero. Particularly high minus values are calculated for COD (chemical oxygen demand), sulphates, chlorides, suspended solids. In fact these substances are especially highly concentrated in leachate from the sanitary landfills $[9,15,23,24]$.

It is not very convincing that municipal waste management system with large treatment installations positively impacts upon the water environment, what implies from the results shown in Table 3.

\subsection{Impact Categories}

The emissions to air are expressed in six impact categories: carcinogens, respiratory inorganics, climate change, respiratory organics, acidification/eutrophication and ecotoxicity (Fig. 2).

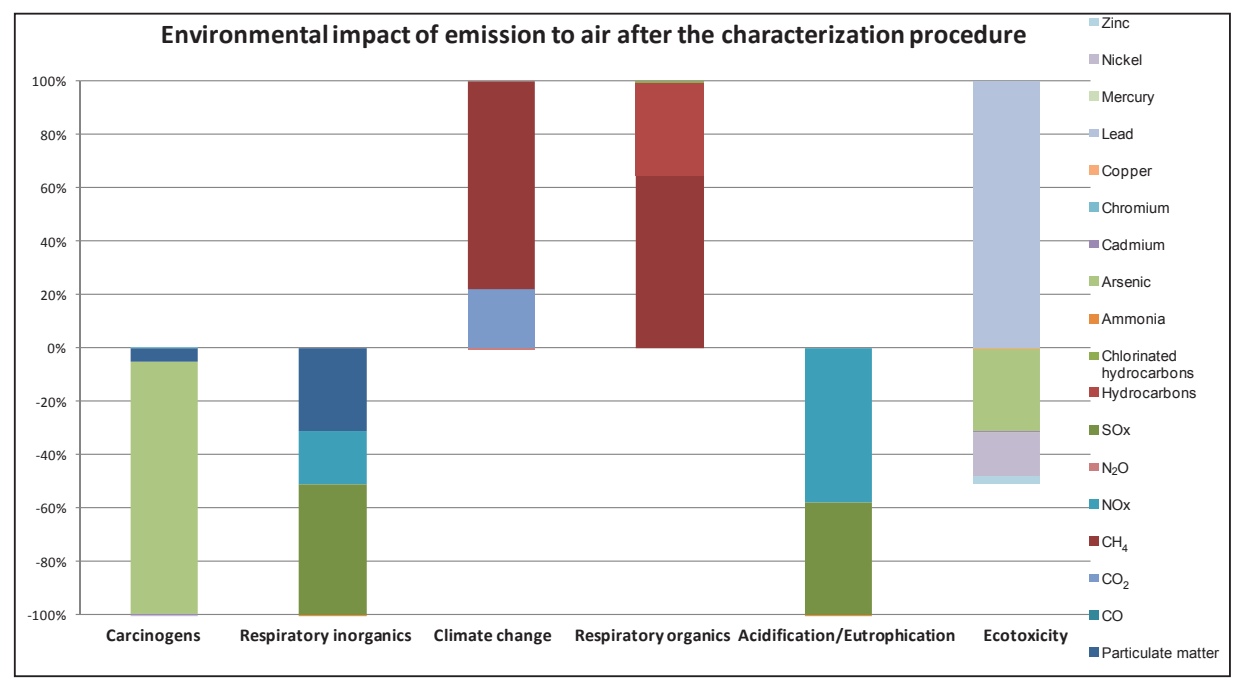

Fig. 2. Environmental impact of emissions to air, after the characterization procedure Source: author's own based on the IWM-PL model 
The indicators for each impact category are calculated, but as they have different units, they cannot be compared with each other. Therefore the values for each category are scaled up to $100 \%$. Three impact categories have the minus values: carcinogens, respiratory inorganics, acidification/eutrophication. Three impact categories: climate change, respiratory organics and ecotoxicity have plus values. The minus values mean avoided impacts, can be attributed to the electricity production from landfill gas and recycling processes. Furthermore the Figure 2 illustrates which substances contribute to the particular impact categories. For the carcinogens contribute: arsenic and particulate matter; for the respiratory inorganics: $\mathrm{SO}_{x^{\prime}} \mathrm{NO}_{x^{\prime}}$ particulate matter; for climate change: $\mathrm{CH}_{4}$ and $\mathrm{CO}_{2}$; for the respiratory organics: $\mathrm{CH}_{4}$ and hydrocarbons; for acidification/ eutrophication: $\mathrm{SO}_{x^{\prime}} \mathrm{NO}_{\mathrm{x}^{\prime}}$; for the ecotoxicity: lead, arsenic, nickel, and zinc.

The emissions to water are expressed in the same six impact categories: carcinogens, respiratory inorganics, climate change, respiratory organics, acidification /eutrophication and ecotoxicity and shown in Figure 3.

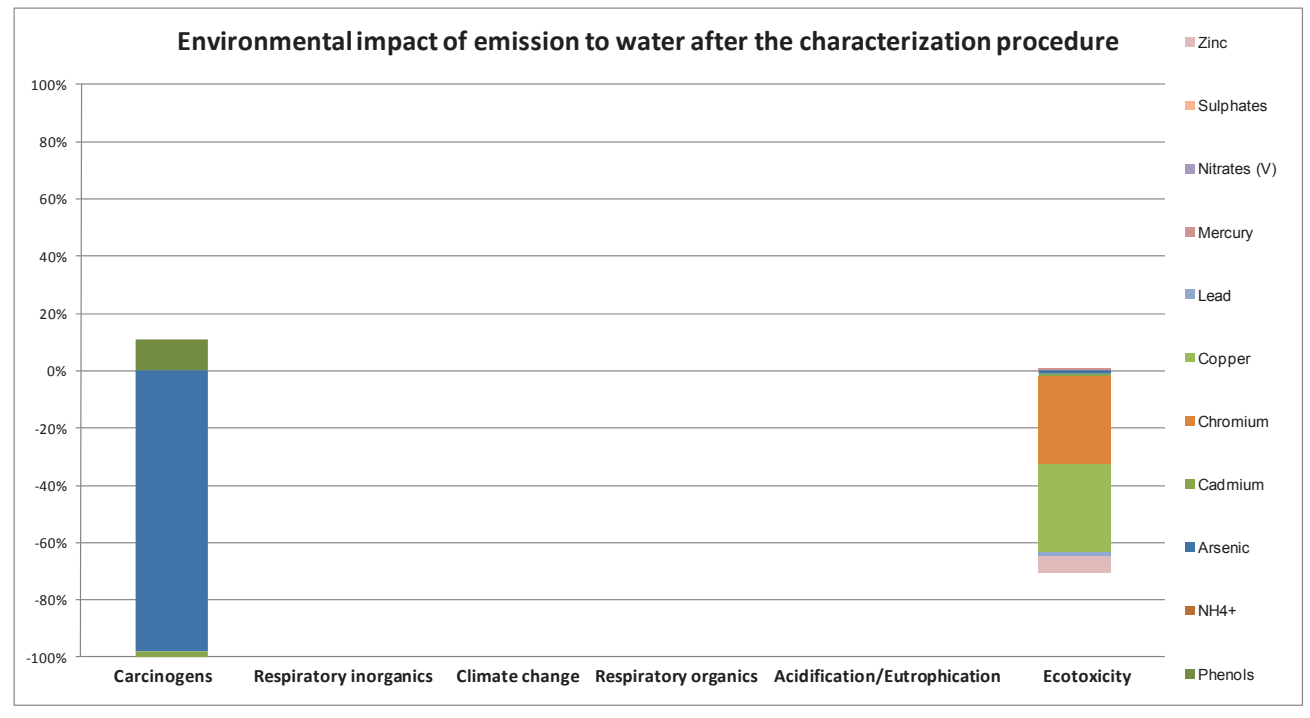

Fig. 3. Environmental impact of emissions to water, after the characterization procedure Source: author's own based on the IWM-PL model

Only for two impact categories: carcinogens and ecotoxicity the values are different than zero, both are below zero. For the impact category carcinogens contribute emissions of substances: arsenic, phenols and cadmium; for the ecotoxicity: chromium, copper, and zinc.

The impact categories with zero values are: respiratory inorganics, respiratory organics, climate change, and acidification/eutrophication. The zero values for 
the respiratory organics, respiratory inorganics and climate change are reasonable, basically emissions to water do not influence the quality of air or climate change. However the zero value for impact category acidification/eutrophication can be hardly explained, bearing in mind substantial emissions from a sanitary landfill.

The Figure 3 indicates that the overall impact of the waste management system on the water environment is positive (avoiding impacts), which seems unlikely. This issue have been already discussed below the Table 3 .

After the step of characterization the normalisation procedure is applied, and the normalised values in impact categories, expressed in ecopoints $(\mathrm{Pt})$ as the units, can be compared. The next step is weighting the results of weighting are shown in Figures 4 and 5 .

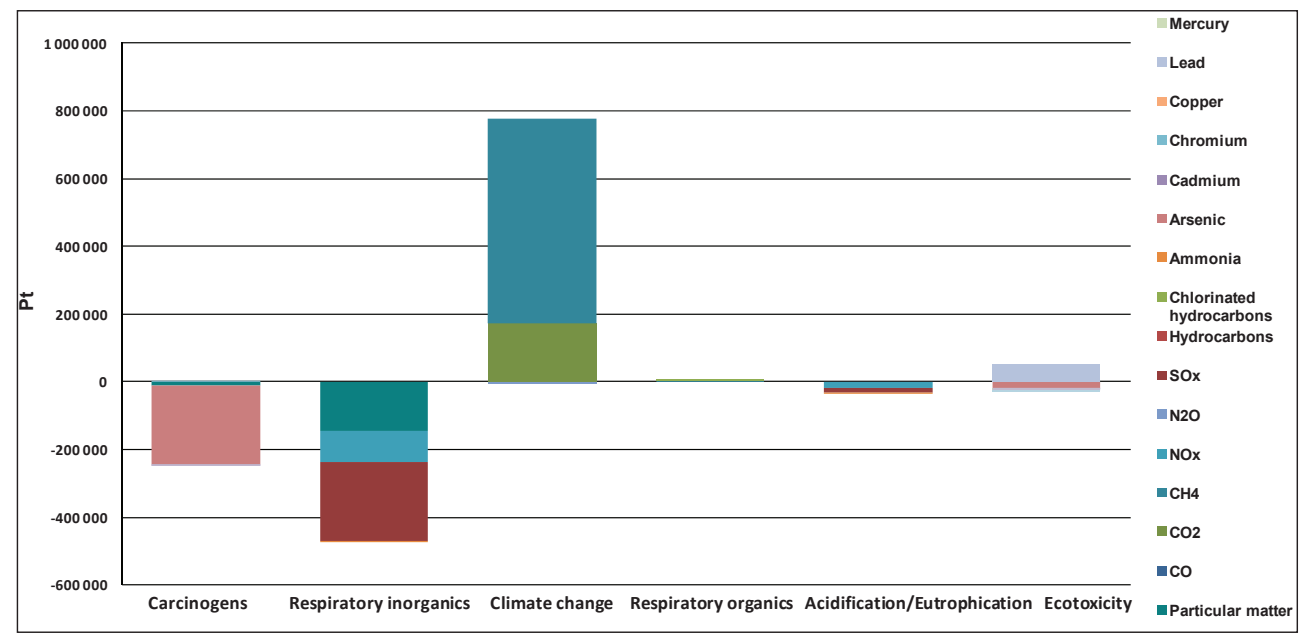

Fig. 4. Environmental impact of emissions to air after the weighting procedure Source: author's own based on the IWM-PL model

For environmental impact of emissions to air, the biggest value is observed in the climate change impact category $(775,769 \mathrm{Pt})$, due to emissions of $\mathrm{CH}_{4}$ and $\mathrm{CO}_{2}$ from the landfilling process. The minus values are observed for respiratory inorganics impact category $(-468,877 \mathrm{Pt})$ - avoided impact contributed to avoided emissions of $\mathrm{SO}_{\mathrm{x}^{\prime}} \mathrm{NO}_{\mathrm{x}^{\prime}}$ particulate matter; and for the carcinogens impact category $(-244,137 \mathrm{Pt})$ - avoided emission of arsenic. Lower values are observed for: ecotoxicity, acidification/eutrophication, and respiratory organics impact categories. Plus values are observed for ecotoxicity $(28,359 \mathrm{Pt})$ mainly due to the emission of lead; and respiratory organics $(1,757 \mathrm{Pt})$ due to the emission of $\mathrm{CH}_{4}$. The minus value is observed for acidification/eutrophication $(-31,144 \mathrm{Pt})$, due to avoided emission of $\mathrm{NO}_{x^{\prime}}, \mathrm{SO}_{x^{\prime}}$ Ammonia. 


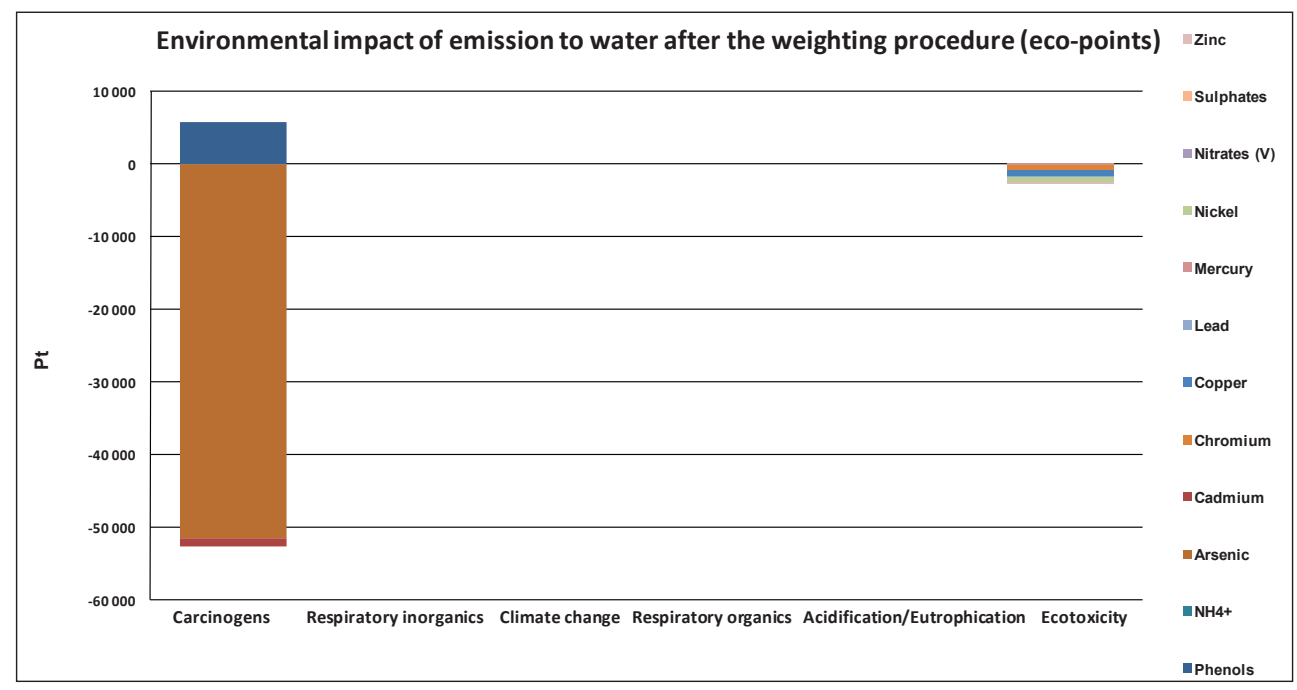

Fig. 5. Environmental impact of emissions to water after the weighting procedure Source: author's own based on the IWM-PL model

After the weighting procedure, for the environmental impacts of emissions to water, only minus values are observed in two impact categories: carcinogens $(-46,751$ $\mathrm{Pt})$ mainly due to the avoided emission of arsenic and ecotoxicity $(-1,766 \mathrm{Pt})$, due to the avoided emission of heavy metals: copper, nickel, zinc.

\subsection{Damage Categories}

The final result of the evaluation of the municipal waste management system is expressed in ecopoints in two damage categories: human health and ecosystem quality. The final result is illustrated in Figure 6.

The negative environmental impact of the municipal waste management system in Krakow is observed only for one damage category: human health, it is $16,726.26 \mathrm{Pt}$ (ecopoints). While for the damage category: ecosystem quality the environmental impact is positive (value below zero), it is $-7,422.14 \mathrm{Pt}$ (ecopoints). As the methodology for life cycle impact assessment in the IWM-PL model is based on the Eco-indicator 99, the damage category human health is related to the following impact categories: carcinogens, respiratory organics, respiratory inorganics and climate change. (Impact categories: the ozone layer and the radiation are not present in the IWM-PL model).

For those impact categories, for emissions to air, both plus and minus values are observed. Plus values for climate change $(775,769 \mathrm{Pt})$ and respiratory organics $(1,757 \mathrm{Pt})$; minus values for respiratory inorganics $(-468,877 \mathrm{Pt})$ and carcinogens $(-244,137 \mathrm{Pt})$. For emission to water only for carcinogens $(-46,751 \mathrm{Pt})$ the minus value is observed. The values of the remaining impact categories related to human health, for emission to water, are zero. 


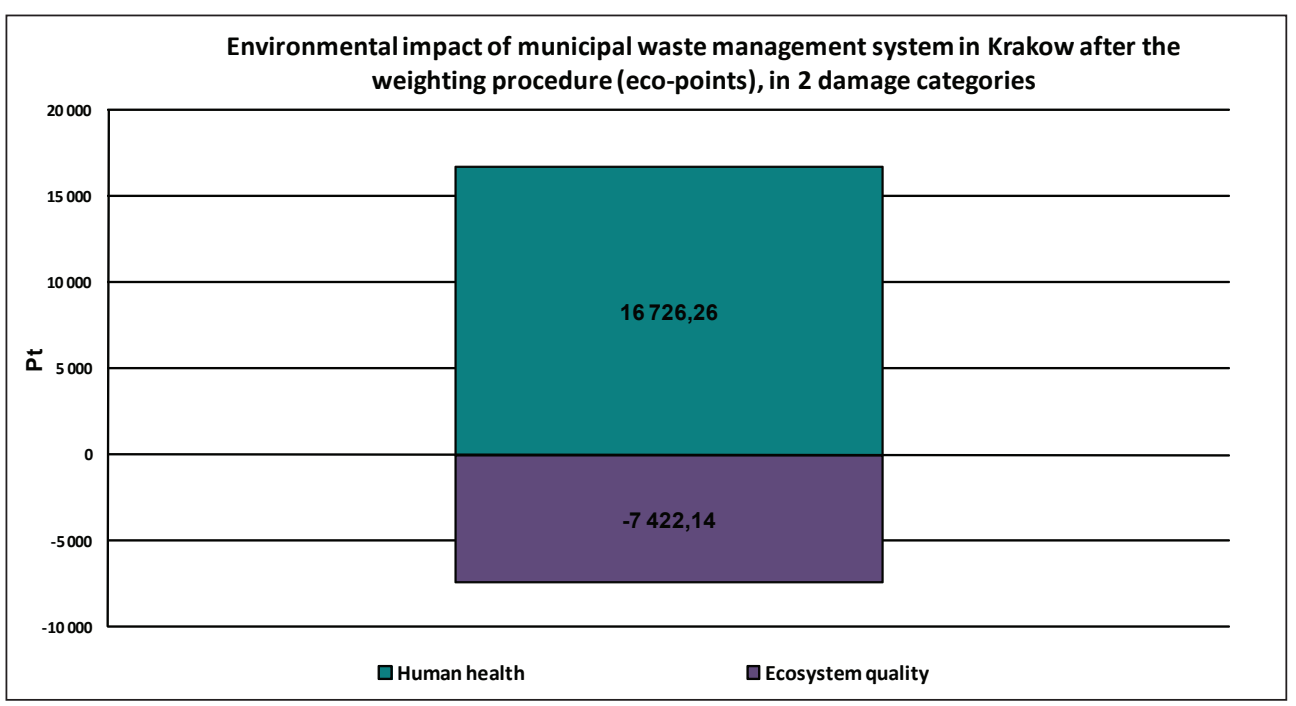

Fig. 6. Environmental impact of municipal waste management system in Krakow after the weighting procedure in two damage categories

Source: author's own based on the IWM-PL model

The final result for human health damage category is calculated as $16,726.26 \mathrm{Pt}$ (ecopoints), which is comparable to the annual environmental load of 16 average European inhabitants.

The damage category: ecosystem quality, in the model IWM-PL, is related to the impact categories: the ecotoxicity and acidification/eutrophication. (The impact category land use is not present in the IWM-PL model).

For emissions to the air, the plus value is observed for ecotoxicity $(28,359 \mathrm{Pt})$ and minus value is observed for acidification/eutrophication $(-31,144 \mathrm{Pt})$. For emissions to the water only minus value is observed for ecotoxicity $(-1,766 \mathrm{Pt})$.

The final result for the damage category: ecosystem quality is calculated as $-7,422.14 \mathrm{Pt}$ (ecopoints), what is comparable to the avoided environmental load of 7 average European inhabitants caused annually.

\section{Summary and conclusions}

1. LCA which was initially developed for evaluating the life cycle of a products, can be also used for evaluating waste management systems. This is usually done by employing a model. The goal of this study is the quantification of the environmental impacts from the municipal waste management system in Krakow - state in 2010, by employing the IWM-PL model, the Polish language application for LCA of waste management systems. 
2. The IWM-PL model generates the Sankey's diagram with waste streams flow between the treatment processes with inputs and outputs, then calculates the emissions to air and water. Calculated emission to air are credible, impacts on air is high due to large emission quantities of $\mathrm{CO}_{2}$ and $\mathrm{CH}_{4}$. There is also a positive impact of emission to air resulting from avoided impacts from recycling of secondary materials and production of electricity from landfill gas. The calculated emission to water are doubtful, because most substances have negative values, meaning a positive impact on the environment. It is not very probable knowing that the landfill process generates huge quantities of leachate and bearing in mind that vast majority of municipal waste in Krakow is disposed at a landfill.

3. The final result of the evaluation of the municipal waste management system in Krakow is expressed in ecopoints $(\mathrm{Pt})$ in two damage categories: human health and ecosystem quality. For human health, the environmental impact of the waste management system is negative and amounts 16,726.26 Pt. While for ecosystem quality the environmental impact is positive (value below zero), and equals $-7,422.14 \mathrm{Pt}$.

4. In order to obtain reliable result of LCA of the municipal waste management system in Krakow further research is needed. The results shown in this paper need to be verified applying other models for LCA developed for evaluating waste management systems. Also, the IWM-PL model requests verification and conducting LCA studies for other waste management systems with other data.

\section{References}

[1] Bare J.C.: Developing a Consistent Decision-Making Framework by Using the U.S. EPA's TRACI Systems Analysis Branch, Sustainable Technology Division, National Risk Management. Research Laboratory, US Environmental Protection Agency, Cincinnati, OH, 2002, [on-line:] http://www.epa.gov/ ORD/NRMRL/std/sab/traci/aiche2002paper.pdf [access: February 4, 2013].

[2] Brand G., Braunschweig A., Scheidegger A., Schwank O.: Weighting in Ecobalances with the Ecoscarcity Method - Ecofactors 1997. BUWAL (SAFEL) Environment Series, no. 297, Bern 1998.

[3] Crettaz P., Rhomberg L., Brand K., Pennington D.W., Jolliet O.: Assessing Human Health Response in Life Cycle Assessment using ED10s and DALYs: Carcinogenic Effects. International Journal of Risk Analysis, vol. 22(5), 2002, pp. 929-944.

[4] De Schryver A.M., Brakkee K.W., Goedkoop M.J., Huijbregts M.A.J.: Characterization Factors for Global Warming in Life Cycle Assessment Based on Damages to Humans and Ecosystems. Environmental Science and Technology, vol. 43(6), 2009, pp. 1689-1695. 
[5] Dreyer L.C., Niemann A.L., Hauschild M.Z.: Comparison of Three Different LCIA Methods: EDIP97, CML2001 and Eco-indicator 99: Does it matter which one you choose? International Journal of Life Cycle Assessment, vol. 8(4), 2003, pp. 191-200.

[6] EN ISO 14040:2006: Environmental management - Life cycle assessment principles and framework. CEN European Committee for Standardization, Brussels 2006.

[7] EPA U.S. Environmental Protection Agency: Life Cycle Assessment: Principles and Practice. EPA/600/R-06/060, May 2006.

[8] European Commission, Joint Research Centre, Institute for Environment and Sustainability: ILCD Handbook: Analysing of existing Environmental Impact Assessment methodologies for use in Life Cycle Assessment. $1^{\text {st }}$ ed. 2010.

[9] Fudala-Książek S.: Wpływ zrzutu odcieków składowiskowych na efektywność pracy miejskiej oczyszczalni ścieków. Politechnika Gdańska, Gdańsk 2011 [Ph.D. thesis].

[10] Goedkoop M., Spriensma R.: The Eco-indicator 99: A Damage Oriented Method for Life Cycle Impact Assessment. Methodology Report. B.V. Amersfoort, The Netherlands, 2001.

[11] Górzyński J.: Podstawy analizy środowiskowej wyrobów i obiektów. Wydawnictwa Naukowo-Techniczne, Warszawa 2007.

[12] Grzesik K.: Application of the IWM-PL Model for the Life Cycle Assessment (LCA) of Municipal Waste Management in Krakow. Part 1. Geomatics and Environmental Engineering, vol. 7, no. 30, pp. 35-55.

[13] Guinée J.B. (Ed.).: Handbook on Life Cycle Assessment: Operational Guide to the ISO Standards. Eco-Efficiency in Industry and Science, vol. 7, Kluwer Academic Publishers, Dordrecht 2002.

[14] Hauschild M., Potting J.: Spatial differentiation in life cycle impact assessment - the EDIP2003 methodology. Environmental News, no. 80, The Danish Ministry of the Environment, Environmental Protection Agency, Copenhagen 2005.

[15] Heyer K.-U., Stegmann R.: Leachate management: leachate generation, collection, treatment and costs. 2001, [on-line:] http://www.ifas-hamburg.de/pdf/ leachate.pdf [access: September 2012].

[16] Itsubo N., Sakagami M., Washida T., Kokubu K., Inaba A.: Weighting across Safeguard Subjects for LCIA through the Application of Conjoint Analysis. International Journal of Life Cycle Assessment, vol. 9(3), 2004, pp. 1996-2005.

[17] Kemna R., Elburg M. van, Li W Holstein R. van: MEEUP - the Methodology Report. European Commission, Brussels 2005 [Final version, Delft 28.11.2005].

[18] Kowalski Z., Kulczycka J., Góralczyk M: Ekologiczna ocena cyklu życia procesów wytwórczych (LCA). Wydawnictwo Naukowe PWN, Warszawa 2007. 
[19] Kraszewski A., Pietrzyk-Sokulska E. (red.): Ocena systemu gospodarki odpadami. Wydawnictwo Instytutu Gospodarki Surowcami Mineralnymi i Energią Polskiej Akademii Nauk, Kraków 2011.

[20] Lewandowska A.: Środowiskowa ocena cyklu życia produktu na przykładzie wybranych pomp przemysłowych. Wydawnictwo Akademii Ekonomicznej w Poznaniu, Poznań 2006.

[21] Pennington D., Potting J., Finnveden G., Lindeijer E., Jolliet O., Rydberg T., Rebitzer G.: Life cycle assessment. Part 2: Current impact assessment practice. Environment International, vol. 30(5), 2004, pp. 721-739.

[22] Steen B.: A systematic approach to environmental priority strategies in product development (EPS). Version 2000-Models and data of the default method. CPM report 1999:5, Chalmers University of Technology, Gothenburg, Sweden, 1999.

[23] Szpadt R.: Usuwanie i oczyszczanie odcieków ze składowisk odpadów komunalnych. Przegląd Komunalny, vol. 12(183), 2006, pp. 60-66.

[24] Szpadt R.: Wysypiska odpadów komunalnych, charakterystyka odcieków. Biuletyn Informacyjny COIB, vol. 4, 1988, pp. 72-76.

[25] Toffoletto L., Bulle C., Godin J., Reid C., Deschênes L.: LUCAS - A New LCIA Method Used for a Canadian-Specific Context. International Journal of Life Cycle Assessment, vol. 12(2), 2007, pp. 93-102.

[26] UNEP/SETAC: Life Cycle Approaches - the Road from Analysis to Practice. UNEP/SETAC Life Cycle Initiative, United Nations Environment Programme. Division of Technology, Industry and Economics, Paris 2005.

[27] Wenzel H., Hauschild M.Z., Alting L.: Environmental assessment of products. Vol. 1: Methodology, tools and case studies in product development. Chapman \& Hall, Kluwer Academic Publishers, Hingham 1997. 